\title{
Investigation of the Physico-Chemical Parameters and Plankton Biotopes of the Nta Wogba Creek, Diobu, Port Harcourt
}

\author{
Roseline Feechi Njoku Tony ${ }^{1,}$, Dike Henry Ogbuagu ${ }^{1}$, Tochi Ezechi Ebe ${ }^{1}$, Monica Nweke Ezike ${ }^{2}$, \\ Irene Ogechi Egbuawa ${ }^{1}$, Grace Ebele Amaku ${ }^{1}$, Eric Chinonso Ezikeudu ${ }^{1}$, Kelechi Nwancho Ogboji ${ }^{1}$ \\ ${ }^{1}$ Department of Environmental Technology, School of Environmental Sciences, Federal University of Technology, Owerri, Nigeria \\ ${ }^{2}$ Department of Animal and Environmental Biology, Faculty of Sciences, Imo State University, Owerri, Nigeria
}

Email address:

tonyrosefeechi@yahoo.com (R. F. N. Tony)

${ }^{*}$ Corresponding author

\section{To cite this article:}

Roseline Feechi Njoku Tony, Dike Henry Ogbuagu, Tochi Ezechi Ebe, Monica Nweke Ezike, Irene Ogechi Egbuawa, Grace Ebele Amaku, Eric Chinonso Ezikeudu, Kelechi Nwancho Ogboji. Investigation of the Physico-Chemical Parameters and Plankton Biotopes of the Nta Wogba Creek, Diobu, Port Harcourt. Journal of Water Resources and Ocean Science. Vol. 7, No. 3, 2018, pp. $20-27$. doi: $10.11648 /$ j.wros.20180703.11

Received: May 3, 2018; Accepted: May 30, 2018; Published: July 25, 2018

\begin{abstract}
Physicochemical parameters could help to reduce or otherwise contribute to the growth and survival of plankton biotopes in the water bodies. This study investigated the physicochemical parameters and plankton biotopes of Ntawogba creek in Port Harcourt, River state. Water samples were collected from five stations representing upstream and downstream. Electrical conductivity (EC), pH, Dissolved oxygen (Do), Chemical oxygen demand (COD), Biochemical oxygen demand (BOD), Nitrate, and Phosphate were determined under standard laboratory methods. Zooplankton and Phytoplankton abundance were also determined. Concentrations of Electrical Conductivity (Range $=860.00 \mu \mathrm{S} / \mathrm{cm}$ ) and Chemical Oxygen Demand, (Range $=31.80 \mathrm{mg} / \mathrm{L}$ ) varied widely, the other parameters had narrow variations. $\mathrm{pH}, \mathrm{EC}$ and Phosphate ion concentrations varied from $7.06-8.27(7.54 \pm 0.23), 395.00-1255.00(722.40 \pm 160.47) \mu \mathrm{S} / \mathrm{cm}$ and $0.01-0.04(0.03 \pm$ $0.01) \mathrm{mg} / \mathrm{L}$ respectively. Nitrate ion concentrations varied from $0.63-5.34(3.41 \pm 0.77) \mathrm{mg} / \mathrm{L}$ while Dissolved Oxygen varied from $0.00-4.90(2.92 \pm 0.84) \mathrm{mg} / \mathrm{L}$. BOD and COD ranged as follows: $2.80-22.70(14.20 \pm 4.21) \mathrm{mg} / \mathrm{L}$ and $4.50-36.30$ $(22.72 \pm 6.74) \mathrm{mg} / \mathrm{L}$ respectively. Phytoplanktons recorded are as follows: Bacilariophytes (291 species), Euglenophytes (68 species) and cyanophyceae (139 species) while zooplanktons identified are protozoans (37 species), copepods (19 species), cladocera (462 species) and rotifers (100 species). This study therefore suggests high pollution impact occasioned by heavy municipal waste discharges and recommends that the government should evolve better solid and liquid waste management policies and practices. The government agencies should enforce all relevant environmental laws, standards and regulations as well as industry operators to treat industrial effluent before disposal into public drain.
\end{abstract}

Keywords: Pollution, Municipal, Planktons, Physicochemical, Bacteriological, Waste Disposal

\section{Introduction}

Rapid urbanization and population explosion in the cities have tremendously resulted to increase in solid waste generation. This in addition to poor waste management has left an unbearable stress on the environment causing degradation and degeneration of its physical, chemical and biological components such as water, air, land and general aesthetics.

The greatest public health concern about these water bodies especially is the ever increasing number and level of toxic substances including heavy metals such as lead, mercury, cadmium, selenium, arsenic and chromium; Organic chemicals such as pesticides, chloroform benzene, carbon tetrachloride, vinyl chloride, polychlorinated biphenyls (PCBs), trihalomethanes, and other toxic constituents e.g. cyanide, nitrate, fluoride and radioactive substances 
introduced into them (Akhionbare, 2009).

Unhealthy waste management practices such as direct introduction of untreated spent oil, solid and liquid waste into the creek have greatly affected its physical, chemical and biological quality.

This necessitated the need to investigate the physicochemical and bacteriological characteristics of the water body.

\section{Study Area}

Port Harcourt City Local Government Area lies along Bonny River and is located in River state in the Niger Delta region with a landmark of about three hundred and sixty (360) km, (140sqmiles). The city features a tropical monsoon climate with lengthy and heavy rainy season and short dry season in December and January. Port Harcourt city lies within humid tropical rain forest zone of Nigeria and on an elevation of $18 \mathrm{~m}$ above sea level at the western corner of river state on coastal plain sand.

Ntawogba creek is located in Port Harcourt City, the stream lies between latitude $4^{\circ} 5^{\prime} \mathrm{N}$ and $5^{\circ} 00^{\prime} \mathrm{N}$ and Longitude $6^{\circ} 55^{\prime} \mathrm{E}$ and $7^{\circ} 00^{\prime \prime} \mathrm{E}$. and an annual rainfall is about 2,500mm (Obianefo, 2006).

Diobu is a place known for high level of economic activities which include automobile workshops, abattoirs, hotels, restaurants, car wash shops, industries and bakeries. There are also civil and public servants.

\section{Methodology}

\subsection{Sample Collection}

\subsubsection{Physicochemical Analysis}

Water samples were collected with a 2 litre amber bottles at subsurface level, stored in an ice chest before taken to the laboratory for analysis.

\subsubsection{Laboratory Procedure}

Laboratory analysis for both physicochemical parameters and Plankton biotopes was carried out.

\subsubsection{Physicochemical Parameters}

Physicochemical parameters were analyzed by employing the methods as described by APHA (1998).

\subsubsection{Phytoplankton and Zooplankton}

Samples were collected in Polyethylene bottle by submerging the bottle below subsurface level. Immediately after collection, $5.00 \mathrm{ml}$ of $10 \%$ formalin was used to fix $100 \mathrm{ml}$ of the sample.

\subsubsection{Phytoplankton Analysis}

The preserved samples were allowed to stand for 48 hours to allow the settlement of organisms. The supernatant was pipette off leaving $5.00 \mathrm{ml}$ of concentrated sample from which sub samples were taken for identification and enumeration counting was done at 200x magnification and the technique followed APHA (1998). The pipette content was transferred into Sedge wick - Rafter counting chamber for enumeration using the reports of Patrick and Reimer (1966), Durand and Leveque (1980) and Chindah and Pudo (1991).

\subsubsection{Zooplankton Analysis}

The same method used in phytoplankton analysis was also used to analyze zooplankton as well as in counting.

\subsubsection{Statistical Analysis}

Ensuing data were analyzed with descriptive statistics, analysis of variance (ANOVA) and Pearson Product Correlation Coefficient.

\section{Results}

Wide variation was observed in the concentrations of Electrical Conductivity (EC) (Range $=860.00 \mu \mathrm{S} / \mathrm{cm}$ ) and Chemical Oxygen Demand (COD) (Range $=31.80 \mathrm{mg} / \mathrm{L}$ ), while the other parameters had narrow variations. $\mathrm{pH}, \mathrm{EC}$ and Phosphate ion concentrations varied from $7.06-8.27$ $(7.54 \pm 0.23) \mathrm{mg} / \mathrm{L}, 395.00-1255.00(722.40 \pm 160.47) \mu \mathrm{S} / \mathrm{cm}$ and $0.01-0.04(0.03 \pm 0.01) \mathrm{mg} / \mathrm{L}$ respectively. (Table 2$)$. Nitrate ion concentrations varied from $0.63-5.34$ (3.41 \pm $0.77) \mathrm{mg} / \mathrm{L}$ while Dissolved Oxygen (DO) varied from 0.00 $4.90(2.92 \pm 0.84) \mathrm{mg} / \mathrm{L}$. However, BOD and COD varied as follows: $2.80-22.70(14.20 \pm 4.21) \mathrm{mg} / \mathrm{L}$ and $4.50-36.30$ $(22.72 \pm 6.74) \mathrm{mg} / \mathrm{L}$ respectively.

Table 1. Physicochemical Parameters of Ntawogba Creek in Port Harcourt, Rivers state.

\begin{tabular}{|c|c|c|c|c|c|c|c|}
\hline Sample Code & pH & Electrical Conductivity $(\mu \mathrm{S} / \mathrm{cm})$ & Phosphate (mg/L) & Nitrate $(\mathrm{mg} / \mathrm{L})$ & DO (mg/L) & BOD (mg/L) & COD $(\mathrm{mg} / \mathrm{L})$ \\
\hline Station 1 & 7.06 & 458 & 0.03 & 3.87 & 4.1 & 17.1 & 27.4 \\
\hline Station 2 & 7.77 & 395 & 0.02 & 5.34 & 4.9 & 22.7 & 36.3 \\
\hline Station 3 & 7.07 & 570 & 0.03 & 3.52 & 3.2 & 5.7 & 9.1 \\
\hline Station 4 & 7.51 & 1255 & 0.01 & 3.71 & 2.4 & 2.8 & 4.5 \\
\hline Station 5 & 8.27 & 914 & 0.04 & 0.63 & 0.0 & 22.7 & 36.3 \\
\hline
\end{tabular}

BOD $=$ Biochemical Oxygen Demand DO = Dissolved Oxygen; COD: Chemical Oxygen Demand

Table 2. Minimum, maximum, mean and ranges of the physicochemical Parameters of Nta wogba stream in Port Harcourt, Rivers state.

\begin{tabular}{lllllll}
\hline Parameters & Minimum & Maximum & Range & Mean & SE & NESREA Standards \\
\hline $\mathrm{PH}$ & 7.06 & 8.27 & 1.21 & 7.54 & 0.23 \\
$\mathrm{EC}(\mu \mathrm{S} / \mathrm{cm})$ & 395.00 & 1255.00 & 860.00 & 722.40 & 160.47 \\
$\mathrm{PO}_{4}{ }^{3-}(\mathrm{mg} / \mathrm{L})$ & 0.01 & 0.04 & 0.03 & 0.03 & 0.01 & 1200 \\
\hline
\end{tabular}




\begin{tabular}{lllllll}
\hline Parameters & Minimum & Maximum & Range & Mean & SE & NESREA Standards \\
\hline $\mathrm{NO}_{3}(\mathrm{mg} / \mathrm{L})$ & 0.63 & 5.34 & 4.71 & 3.42 & 0.77 & 40 \\
$\mathrm{DO}(\mathrm{mg} / \mathrm{L})$ & 0.00 & 4.90 & 4.90 & 2.92 & 0.84 & Not Available \\
$\mathrm{BOD}(\mathrm{mg} / \mathrm{L})$ & 2.80 & 22.70 & 19.90 & 14.20 & 14.21 & 15 \\
$\mathrm{COD}(\mathrm{mg} / \mathrm{L})$ & 4.50 & 36.30 & 31.80 & 22.72 & 6.74 & 15 \\
\hline
\end{tabular}

$\mathrm{SE}=$ Standard error of mean, $\mathrm{EC}=$ Electrical Conductivity.

\subsection{Spatial Variations in Physicochemical Parameters}

Variations were observed in the concentrations of the physicochemical parameters measured. The least concentrations of $\mathrm{pH}$ (7.06), Phosphate ions $(0.01 \mathrm{mg} / \mathrm{L})$ and Nitrate ions $(0.63 \mathrm{mg} / \mathrm{L})$ were recorded in Sampling stations (SSs) 1, 4 and 5, while their maximum concentration of 8.27 , $0.04 \mathrm{mg} / \mathrm{L}$ and $5.34 \mathrm{mg} / \mathrm{L}$ were recorded in SS 5, SS 5 and SS 2 respectively (Figure 1.)

Minimum concentrations of EC $(395.00 \mu \mathrm{S} / \mathrm{cm})$ and COD $(4.50 \mathrm{mg} / \mathrm{L})$ were recorded in $\mathrm{SS} 2$ and $\mathrm{SS} 4$, while highest concentrations of $1255.00 \mu \mathrm{S} / \mathrm{cm}$ and $36.30 \mathrm{mg} / \mathrm{L}$ were recorded in SS4 and SS2 respectively.

DO and BOD recorded least concentrations of $0.00 \mathrm{mg} / \mathrm{L}$ and $2.80 \mathrm{mg} / \mathrm{L}$ in SS5 and SS4 and maximum concentrations of $4.90 \mathrm{mg} / \mathrm{L}$ and $22.70 \mathrm{mg} / \mathrm{L}$ in $\mathrm{SS} 2$ and $\mathrm{SS} 2 / \mathrm{SS} 5$ respectively.

The analysis of Variance (ANOVA) test revealed that the concentrations of the physicochemical parameters differed significantly across the sampling stations. $\left[\mathrm{F}_{(5.08)}>\mathrm{Fcrit}_{(3.98)}\right]$ at $\mathrm{P}<0.05$.

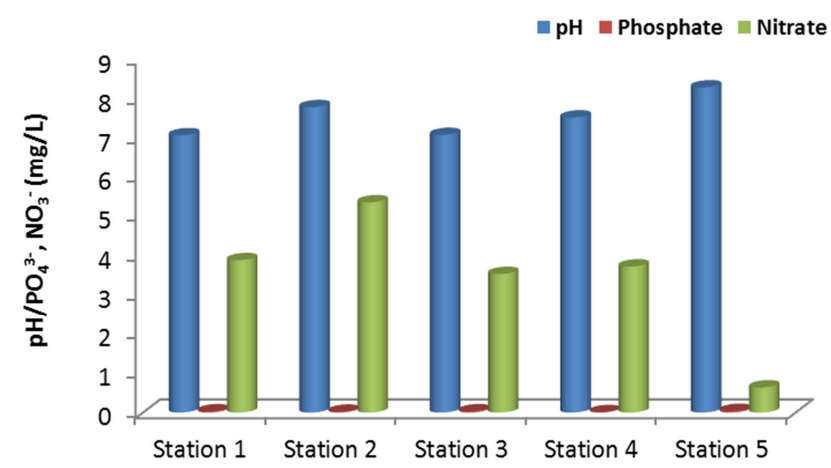

Figure 1. Spatial Variation in levels of $p H$, phoshate \& nitrate ion concentrations in Ntawogba Creek.

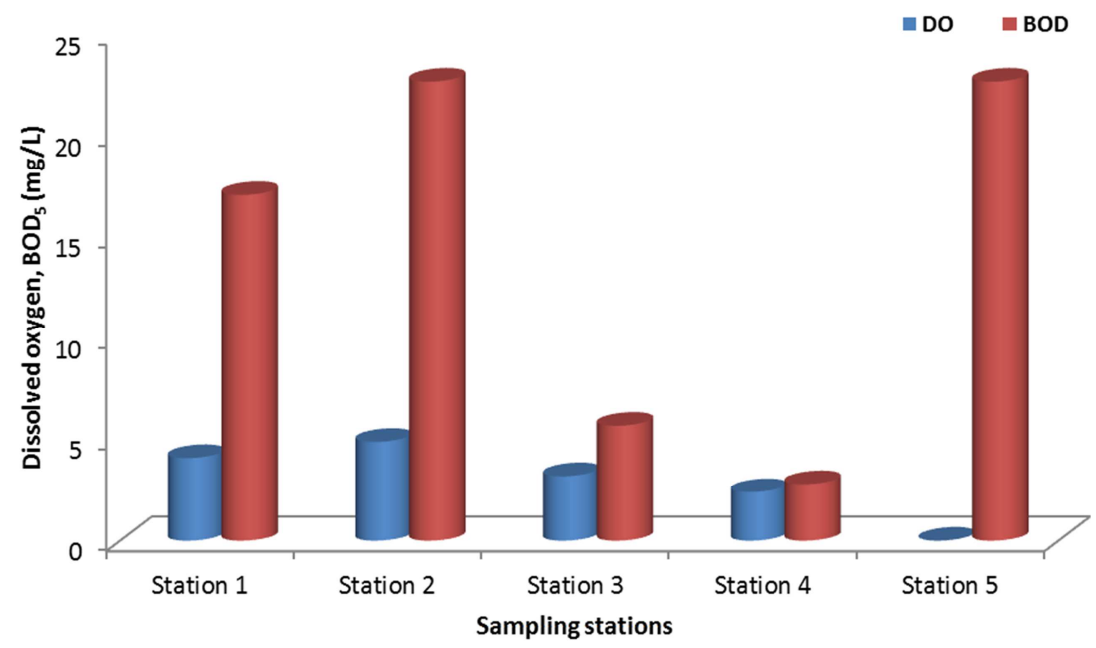

Figure 2. Spatial variations in levels of dissolved oxygen and 5-day biological oxygen demand in Ntawogba creek.

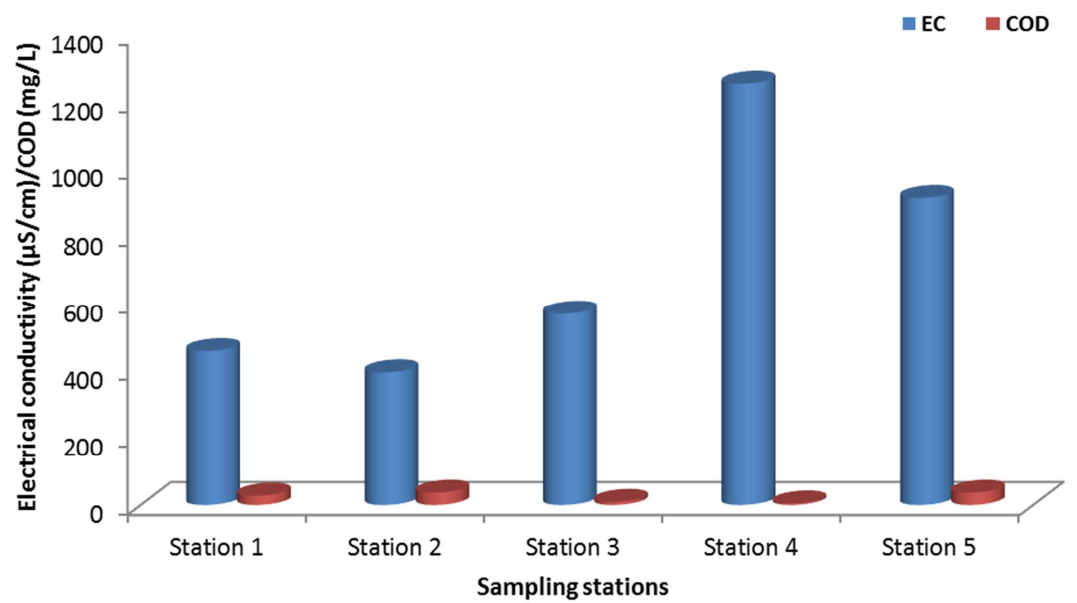

Figure 3. Spatial variations in levels of electrical conductivity and chemical oxygen demand in Ntawogba creek. 


\subsection{Plankton Abundance and Diversity}

The plankton taxa identified in this study varied across the sampling stations. Of the Phytoplankton taxa, the Bacillariophyceaens (Diatoms) had the highest number of species $(28 \mathrm{cells} / \mathrm{ml})$ identified while the Euglenophyceaens had the least number of species $(8$ cells $/ \mathrm{ml})$ identified. The order of abundance of phytoplankton families identified was Bacilariophyceae $>$ Cyanophyceae $>$ Euglenophyceae.

Of the diatoms, the most abundant genera were those of Navicula and Nitzchia (4 genera each), while Melosira, Cyclotella, Tabelleria, Ryoicospheria, Eunotia, Pediastrum and Surirella recorded least abundance (1genus each).

The most abundant genera of the Euglenophyceae family were those of Euglena (3 genera), Trachelomonas (3 genera), Strombonomas (1 genius) and Phacus (1 genius).

Similarly the blue-green algae (Cyanophyceae) were recorded by the following species; Oscillatoria (3 genera), Microcystis (2 genera), Phormidium (2 genera), Dactylococeopsis (1 genus), Anabaena (1 genus),
Synchrococeus (1 genus), Pseudonobaena (1 genus).

Of the zooplankton taxa, the Cladocera had the highest number of species (6 organisms $/ \mathrm{ml}$ ), while Rotifera had the least number of species ( 2 organisms $/ \mathrm{ml}$ ) identified. The order of abundance of the zooplankton families was Cladocera $(6$ organisms $/ \mathrm{ml}$ ) >Protozoa (4 organisms $/ \mathrm{ml}$ ) >Copepoda $(3$ organisms $/ \mathrm{ml})>$ Rotefera $(2$ organisms $/ \mathrm{ml}$ ).

\subsection{Spatial Variations in Plankton Abundance}

One hundred and twenty eight, 94, 54, and $15 \mathrm{cells} / \mathrm{ml}$ of diatoms were recorded in SS1, SS2, SS3 and SS4 respectively (Figure 4). For the Euglenophyceae family, 14, 7, 4, 19 and 24 cells $/ \mathrm{mL}$ of individuals were recorded in SS1, SS2, SS3, SS4 and SS5 respectively. However, for the Cyanobacteria, 31, 25, 41,17 and 25 cells $/ \mathrm{mL}$ of individuals were recorded in SS1, SS2, SS3, SS4 and SS5 respectively, (Figure 4.).

The ANOVA test reveals that the numerical Abundance of the Phytoplankton taxa identified differed significantly across the sampling stations. $\left[\mathrm{F}_{(11.11)}>\right.$ Fcrit $\left._{(4.20)}\right]$ at $\mathrm{P}<0.05$.

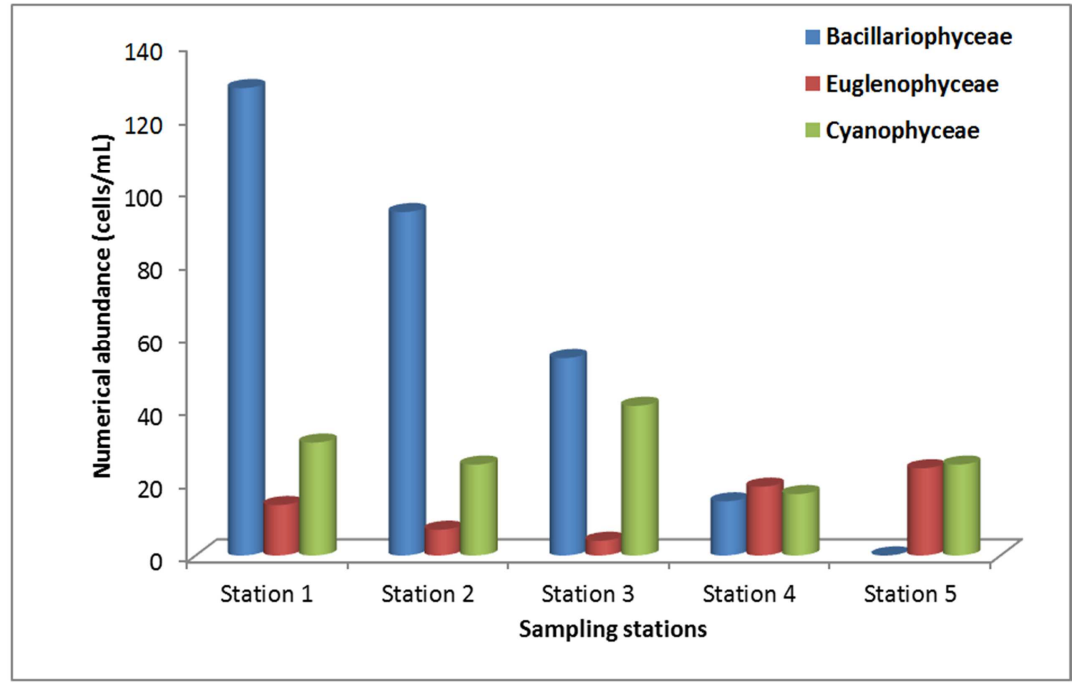

Figure 4. Numerical abundance of phytoplankton taxa in Ntawogba creek.

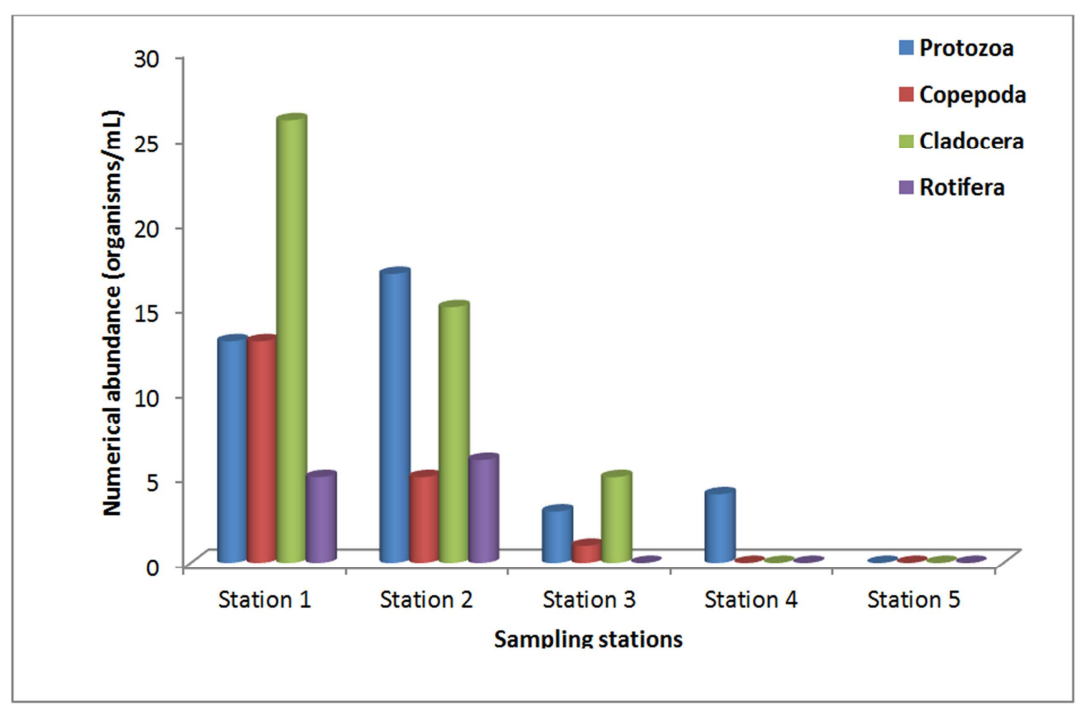

Figure 5. Numerical abundance of zooplankton taxa in Ntawogba creek. 
Of the zooplankton taxa, protozoan abundances were 13, 17, 3, 4 and 0 cell/mL in SS1, SS2, SS3, SS4 and SS5 sampling stations respectively while the Copepoda recorded in SS1, SS2, SS3, SS4 and SS5 sampling stations were 13, 5, 1, 0 and 0 cell $/ \mathrm{mL}$ respectively and cladocera recorded for $\mathrm{SS} 1, \mathrm{SS} 2, \mathrm{SS} 3$, SS4 and SS5 were $26,15,5,0$ and 0 cell $/ \mathrm{mL}$ respectively. Rotifera genera recorded were as follows: 5, 6, 0, 0 and 0 cell/mL in SS1, SS2, SS3, SS4 and SS5 respectively.

\subsection{Plankton Diversity Indices}

The Margalef's Diversity (Richness) index (I) reveals that of the Phytoplankton taxa, the highest diversity of Plankton (I $=6.00$ ) was recorded in SS2 while the least diversity of plankton $(\mathrm{I}=3.08)$ was recorded in SS5 (Table 3.). The spatial order of Margalef's diversity was SS2 (6.00) > SS3 (5.66) $>$ SS1 (5.63) > SS4 (4.58) > SS5 (3.08).

For the zooplankton, $(\mathrm{I}=3.46)$ was recorded in $\mathrm{SS} 1 / \mathrm{SS} 2$ while the least diversity of zooplankton $(\mathrm{I}=0.00)$ was recorded in SS4/SS5. The spatial order of Margalef's diversity was SS1/SS2 (3.46) > SS3 (2.28) > SS4/SS5 (0.00).

Table 3. Diversity (Richness) of Plankton Species in Ntawogba creek Using Margalef's Index (I).

\begin{tabular}{llllll}
\hline \multirow{2}{*}{ Plankton } & \multicolumn{6}{l}{ Sampling stations } \\
\cline { 2 - 6 } & $\mathbf{1}$ & $\mathbf{2}$ & $\mathbf{3}$ & $\mathbf{4}$ & $\mathbf{5}$ \\
\hline Phytoplankton & 5.63 & 6.00 & 5.66 & 4.58 & 3.08 \\
Zooplankton & 3.46 & 3.46 & 2.28 & 0.00 & 0.00 \\
\hline
\end{tabular}

$$
\mathrm{I}=\frac{\mathrm{S}-1}{\operatorname{LognN}}
$$

Where $\mathrm{S}=$ No of Species

$\mathrm{N}=$ Total number of individuals in all the species.

Table 4. Correlation (r) matrix between the Physicochemical Parameters and Plankton Abundance.

\begin{tabular}{lllllll}
\hline & $\mathbf{p H}$ & $\mathbf{E C}$ & $\mathbf{P O}_{4}{ }^{3-}$ & NO $^{-}$ & DO & BOD \\
\hline Bacillariophyceae & -0.592 & -0.831 & -0.031 & 0.681 & 0.856 & 0.268 \\
Euglenophyceae & 0.608 & 0.691 & 0.164 & -0.721 & -0.778 & 0.172 \\
Cyanophyceae & -0.557 & -0.624 & 0.532 & 0.034 & 0.234 & -0.082 \\
Protozoa & -0.252 & -0.700 & -0.309 & 0.810 & 0.877 & -0.082 \\
Copepoda & -0.486 & -0.655 & 0.103 & 0.412 & 0.611 & 0.408 \\
Cladoceae & -0.490 & -0.774 & 0.066 & 0.537 & 0.731 & 0.343 \\
Rotifera & -0.158 & -0.755 & -0.116 & 0.665 & 0.778 & 0.380 \\
\hline
\end{tabular}

$\mathrm{BOD}=$ Biochemical Oxygen Demand, $\mathrm{COD}=$ Chemical Oxygen Demand, PO43-=Phosphate, $\mathrm{DO}=$ Disolved Oxygen

However there was no significant Pearson's Correlation (r) between the Physicochemical parameters and Plankton abundance at both the $95 \%$ and $99 \%$ confidence limits.

\section{Discussion}

Although sampling stations (SS) 1- 4 presented a lower $\mathrm{pH}$ than 8, SS5 (downstream) presented the highest $\mathrm{pH}$ $(8.27 \pm 0.23)$ of all the stations. SS1 (upstream) recorded the least $\mathrm{pH}(7.06 \pm 0.23)$. The range of $\mathrm{pH}$ observed might be due to decreased forest floor drainage area, washing of concrete structures during storm and draining of domestic effluent water to the stream as well as influence of brackish water. The $\mathrm{pH}$ is high when compared to work done by Chindah et al (2005) which could be as a result of the high evaporation associated with the dry season in the tropics. The $\mathrm{pH}$ that tends towards alkalinity is in contrast with the acidic $\mathrm{pH}$ recorded in similar stream where litter fall underlying the stream bed, through the processes of decay, produces humic substances that induce acidic condition (Chindah, 2003). This may be as a result of the concrete underlying of the Ntawogba stream bed which tends to drag the $\mathrm{pH}$ of the stream towards alkalinity.

The almost uniform $\mathrm{pH}$ for all the stations implies that municipal effluent input into the stream do not remarkably alter the $\mathrm{pH}$ of the entire system. This observation however contrasts with that of obunwo et, al., (2004) where higher differences in $\mathrm{pH}$ was observed with the same system. These variations may be due to the fact that the water body's natural processes had been altered following time series changes in the system. For example, between the period of study by Obunwo, et al. (2004) and this, the stream has been dredged to enable the free flow of water and thus reducing stational differences to a minimum.

\subsection{Electrical Conductivity}

The high conductivity values observed along the stream stretch are above the expected limit for such fresh swamp forest streams. The elevated values may be associated with the discharges from the surrounding landmass activities along the course of the stream and domestic sources which contains lots of solutes and other dissolved compounds. The lower conductivity values recorded may also be indicating the role of season in the water body as storm water during the wet season helps to flush the system and dilute the solutes and mineral components. The observed relative higher values in the lower stretch are expected as it receives more municipal discharges than the upper stretch. While SS2 recorded the least value of EC $(395 \pm 160.47)$, SS4 recorded the highest value of EC $(1255 \pm 160.47)$.

\subsection{Phosphate}

The low concentration of phosphate observed in this study is a common feature of tropical fresh water bodies (Chindah and Braide, 2003). The phosphate ion concentration was 
within the range of $0.01-0.04(0.03 \pm 0.01) \mathrm{mg} / \mathrm{L}$. The reason for this low level has been associated with the poor nutrient load of the drainage basin, and the high activity rate of biological organisms that quickly use up the nutrient released into the system (Chindah, and Braide, 2004). In spite of this, the relatively high phosphate concentrations observed in the lower sampling station of the stream may be associated with the nature of the municipal waste discharged. For example the abatoir waste discharged at the Ikokwu abatoir might have been responsible for the preponderance of the blue green observed in the plankton population in some stations (SS3 SS4 and SS5).

In the contrary, Braide, et al. (2004) observed higher level of phosphate in the wet season than in the dry season in the Miniweja stream and the difference might have been due to the differences in location and the nature of activities along the course of the stream.

\subsection{Nitrate}

The concentrations of nitrate (range $=4.71$ ) were generally low for the entire study period $0.63-5.34(3.41 \pm 0.77)$ $\mathrm{mg} / \mathrm{L}$. This can be linked to the nature of the drainage basin which is not generally rich in nitrate. It can also be attributed to the presence of primary producers such as algae which can strip the waste of any added nitrogen (Chindah and Braide, 2004). The reason for the general low nutrient concentration in-spite of the organic load received by the systems may be due to both the high temperature and microbial properties of the water body. Organisms in tropical water bodies are known to quickly use up the nutrients under high temperature condition (Chindah and Braide, 2004). However the concentrations of nitrate were higher in the upper limit of the stream than the lower limit. This pattern nevertheless negates the pattern observed by Obianefo (2006) in the wet season. The reason for high level can be attributed to land run off and discharges from adjoining land masses. In a study on the same stream, Obianefor (2006) observed higher levels of nitrate in the wet season than in the dry season. This could be linked to storm runoff from the land mass in the study area. Some of the land masses are used for small scale agriculture where nitrogen fertilizers could have been applied.

\subsection{Dissolved Oxygen (DO)}

The dissolved oxygen concentration though generally low $0.00-4.90(2.92 \pm 0.84) \mathrm{mg} / \mathrm{L}$ demonstrates a steady decrease downstream. The general low dissolved oxygen concentrations in the downstream and the relatively higher values of oxygen recorded in the upstream stations comparative to the mid and downstream stations implies the depletion of oxygen along the water course as it flows downstream. This may suggest that the more waste are introduced into the stream, the more its dissolved oxygen concentration declines. The relatively higher values of dissolved oxygen observed in the upper stream of the water body may also be traced to the high population of phytoplankton in the upstream and midstream which in the presence of sunlight through the process of photosynthesis releases oxygen into the system as a byproduct. Comparatively, higher dissolved oxygen concentrations were observed by Braide et al (2004) in the Miniweja stream during wet season which may be attributed to increased current inflow and facilitated turbulence that consequently elevate the oxygen concentration during wet season.

\subsection{Biochemical Oxygen Demand $\left(\mathrm{BOD}_{5}\right)$}

Conversely, the $\mathrm{BOD}_{5}$ values (Range $=19.90$ ) are very high $2.80-22.70$ and agrees with the low concentrations of DO in the study area. The stational variation in the $\mathrm{BOD}_{5}$ values reflects the impact of the municipal waste discharge along the stream. This supports the contention that the increased waste load into the system degrades the water quality as the BOD5 values far exceed concentrations reported in the baseline studies of some of these streams (NDBDA 1987, and Ogan 1988) The low oxygen concentrations recorded and the high BOD5 values for all the stations are strong evidence to suggest the impact of organic load introduced from municipal waste into the creek (Rim-Rukeh et. al., 2007, Hill et. al., 2005 and Chen, 2010).

Biological oxygen demand, being a measure of the oxygen in the water that is required by the aerobic aquatic organisms for the biodegradation of organic materials exerts oxygen pressure in the water and increases the biochemical oxygen demand (Ubong et al, 2008). Streams with low BOD5 have low nutrient levels; and this may account for the general low nutrient status of the stream in most cases. The increased concentration of BOD5 implies that oxygen is swiftly depleted in the streams. The consequences of high BOD5 concentrations are that organisms get prone to stress, suffocation, and possible death. This may account for the depletion in the number of phytoplankton in the sampling station 5 (SS5) which recorded the highest $\mathrm{BOD}_{5}$ concentration in the study area.

\subsection{Spatial Variation in Plankton Abundance}

The forty seven phytoplankton species recorded for the entire study period were lower than ninety-one species recorded by Amadi et al. (1997) on the same water body, sixty species reported by Egborge (1999) in warri river, fiftysix species by Nwadiaro and Ezefili, (1986) but slightly higher than forty six species by Chindah (2003) in the Elele Alimini swamp forest stream. The relatively low proportion of species recorded may be related to the nutrient status of the sream. Therefore, the relatively low values observed for the Ntawogba creek may be associated with the nutrient load and other discharges from the municipal sources which may have discouraged the development of species.

The community structure being dominated by diatoms in most of the stations is not in line with the observation made by Amadi et al. (1997) in the same system which recorded more of Cyanophyceae in most of his study locations. Nonetheless, due to low abundance of diatoms in this current study as compared to that recorded by Amadi et al. (1997) 
there is an indication that the stream is polluted and under stress since diatoms can only predominate in unpolluted natural lotic waters in the tropics (Chindah and Braide, 2004) The further abundance of blue-green algae in Olu Obasanjo sampling station may partly be due to the fact that the area has higher organic and inorganic load from adjacent activities such as auto-mechanic workshops and other domestic discharges.

\subsection{Relationships Between the Physicochemical Parameters and Plankton Abundance}

The interrelationship of the various parameters as reflected in the correlation coefficient values re-emphasizes the role of these environmental variables on both the phytoplankton and zooplankton biomass and abundance. Despite the poor nutrient status of the stream, some nutrient parameters (phosphate and nitrate) showed positive association with plankton abundance. These suggest that some of the organisms are utilizing the nutrients and this underscores the importance of these parameters in the primary productivity of any aquatic system (Chindah, 1998).

The positive association of the phytoplankton abundance, $\mathrm{pH}$ and nutrient variables suggest the role which these attributes play in the phytoplankton community. Also the positive association between Phytoplankton and nutrients may be as a result of the stationary nature of the phytoplankton population and the differences in their niche requirement.

Of all the planktonic population, only the Euglenophytes had a negative association with nitrates. Notably, only the Euglenophytes had a positive association with $\mathrm{pH}$. This may support the hypothesis that by comparison with water quality parameters associated with euglenophytes bloom, cell density of euglenophytes increased at acidic environment with higher phosphate and Nitrate concentrations and showed a declining trend at alkaline condition $(\mathrm{pH}>7.0)$ with lower nutrient concentrations (Rim-Rukeh et al.2007), (Rahman et al 2007).

Blue green algae at the station suggests that it has out competed other algal forms due to its ability to tolerate stress condition especially in oil polluted environment as reported by Pudo (1988).

\section{Conclusion}

The concentration of the physicochemical parameters varied significantly across the sampling stations.

The diatoms (Bacillariophyceae) and cladocera dominated the phytoplankton and zooplankton taxa respectively and were most abundant at the SS1.

The nutrients (Po43- and No3-) enhanced planton biotope abundances.

\section{References}

[1] Akhionbare S. M. (2009), The Environment: Concept, Issues $\&$ control of Pollution, 83pp.
[2] Amadi, E. N. Chindah, A. C., Ugoji, C. C. (1997). The effect of municipal drainage on the microflora.

[3] APHA- American Public Health Association (1998). Standard methods for the examination of water and waste water. 20th ed. APHA-AWWA-WPCF. Washington DC. 1220p.

[4] Braide, S. A., Izonfuo W. A. L., Adiukwu, P. U., Chindah, A. C. and Obunwo, C. C. (2004). Water quality of Miniweja stream, A swamp forest stream receiving non - point source waste discharges in Eastern Niger Delta, Nigeria. Scientia Africana 3(1): 1-8.

[5] Chindah, A. C. (1998). "The effect of industrial Activities on the Periphyton Community at the upper reaches of New Calabar River, Niger, Niger Delta, Nigeria" Wat. Res. 32 (4): $1137-1143$.

[6] Chindah, A. C. and Braide, S. A. (2003). Epipelic Algal of tropical estruary: case of stable and invariable seasonal community. Polish Journal of Ecology 51 (1): 91 - 99.

[7] Chindah, A. C. and Braide, S. A (2004). The physicochemical quality and phytoplankton community of tropical waters: A case of 4 biotopes in the lower Bonny River, Niger Delta, Nigeria. Caderno de Pesquisa. Ser. Bio. Santa Cruz do Sul Vol $16(2), 7-37$.

[8] Chindah, A. C., Braide, S. A. and Izundu, E. (2005). Treatment of Municipal Wastewater Quality Using Sunlight. Caderno de Pesquisa. Ser. Bio. Santa Cruz do Sul Vol 17 (2), $27-45$.

[9] Chinda, A. C. and J. Pudo, (1991). A preliminary checklist of algae found in Bony River in Niger Delta. Nigerian GROGM. Flor. Geo-bot., 36(1): 112-125.

[10] Chen G., Cao X. Song C. and Zhou Y. (2010). Adverse Effects of Ammonia on Nitrification Process: the Case of Chinese Shallow Freshwater Lakes. Water Air Soil Pollut. 210:297-306.

[11] Duran, J. L and Leveque (1980) Flora et Fuana equitiques de L'Afrique, Cah. Off. Rech. Sci. Tech. Outremer, 1:5-46.

[12] Egborge, A. B. M. and Fagade, S. O. (1999) Notes on the hydrobiology of the Wikki warm spring, Yankari Game Reserve, Nigeria. Pol. Arch Hydrobiol. 23:313-322.

[13] Hill, D. D., Owens, W. E., and Tchounwou, P. B. C. (2005). Comparative assessment of the physico-chemical and bacteriological qualities of selected streams in Louisiana. Int J Environ Res Public Health. 2(1):94100.

[14] Nwadiaro, C. S and Ezefili (1986) Preliminary checklist on phytoplankton of New Calabar river in Niger Delta. Hydrobiological Bulletin. 19(2) 113- 138.

[15] NDBDA- Niger Delta Basin Development Authority (1987). The Chemical composition of Niger Delta Rivers. Final report on the Environmental Pollution Monitoring of the Niger Delta basin of Nigeria. Vol 5. i-xvii, 1-145.

[16] Ogan M. T (1988) Examination of surface waters used as sources of supply in the Port Harcourt Area 11. Chemical Hydrology. Archiyfuer Hydrobiologie supplement. Vol 79, no 203, pp. 325-342.

[17] Obianefo F. U., (2006). Physicochemical and Biological Characteristics of a Stream Receiving Municipal Discharges in Port Harcourt, 1-20pp. 
[18] Obunwo, C. C., Braide, S. A., Izonfuo, W. A. L. and Chindah, A. C. (2004). Influence of Urban activities on the water quality of a fresh water stream in the Niger Delta, Nigeria. Journal of Nigerian Environmetal Society 2 (2): 196 - 209.

[19] Patrick R. and Reimer, C (1966) the Diatoms of the United States Exclusive of Alaska and Hawaii. 1: Fragillariaceae. NEunotiaceae Achnanthaceae, Naviulaceae. The livingson publishing company Philadelphia, 688pp.

[20] Pudo, J., Fubara, D. M. J. (1988). "Studies on Periphyton Algae in the Petroleum oil spillage Area of the Niger Delta aquatic System". Verh. Int. Ver. Limnol. 23: 2259-2261.
[21] Rahman M. M, Jewel M. A. S, Khan S. And Haque M. M, 2007, Study of Euglenophytes, Bloom and its Impact on Fish groeth in Bangladesh. Algae Vol 22(3): 186-192.

[22] Rim-Rukeh, A., Ikhifa, G. O. and Okokoyo, P. A. (2007). Physico-Chemical Characteristics of Some Waters Used for Drinking and Domestic Purposes in the Niger Delta, Nigeria. Environmental Monitoring and Assessment. 128 (1-3), 475482.

[23] Ubong, I. U. and Gobo, A. E. (2008). Fundamentals of Envronmental Chemistry and Meterology first edition, Tom and Harry Publications pp $83-99$. 